\title{
ANALISIS AZAS-AZAS UMUM PELAYANAN PUBLIK DI DINAS PERINDUSTRIAN DAN PERDAGANGAN KABUPATEN KERINCI
}

\author{
Eliyusnadi \\ Sekolah Tinggi Ilmu Administrasi Nusantara Sakti Sungai penuh \\ Email : \\ eliyusnadistia@gmail.com
}

\begin{abstract}
Analysis of General Principles of Public Service at the Industry and Trade Office of Kerinci Regency. Every community certainly really hopes for the existence of general principles of public services in providing services to the community, especially at the Kerinci Regency Industry and Trade Office. In order to provide satisfactory services to service users, service delivery must meet the general principles of good governance in order to create customer satisfaction, which is a measure of the success of a public service. The formulation of the research problem, namely, how are the general principles of public services at the Kerinci Regency Industry and Trade Service. The objective of the research is to find out the general principles of public services in the Kerinci Regency Industry and Trade Service. This research uses a qualitative approach where data is obtained through field interview guides to 7 informants referring to 6 research indicators, namely 1. Transparency 2. Accountability 3. Conditional 4. Participation 5. NonDiscriminatory. 6. Balance of Rights and Obligations. The data obtained in the field were analyzed based on the classification of the informants' answers which were described in the results and discussion of the research which was then carried out by the interpretative researcher. It is known that the General Principles of Public Service at the Industry and Trade Office of Kerinci Regency, from the six research indicators, five indicators are well implemented, namely accountability, conditionality, participation, non-discrimination and balance of rights and obligations, while transparency indicators have not been maximally implemented. For this reason, the authors suggest that the General Principles of Public Service in the Kerinci Regency Industry and Trade Service can be improved so that they are more transparent in providing services to the community.
\end{abstract}

\section{Keywords: General Principles of Public Service}

\begin{abstract}
ABSTRAK
Analisis Azas-Azas Umum Pelayanan Publik Di Dinas Perindustrian dan Perdagangan Kabupaten Kerinci. Setiap masyarakat tentunya sangat mengharapkan adanya azas-azas umum pelayanan publik dalam memberikan pelayanan kepada masyarakat khususnya pada Dinas Perindustrian dan Perdagangan Kabupaten Kerinci. Agar dapat memberikan pelayanan yang memuaskan bagi pengguna jasa, penyelenggaraan pelayanan harus memenuhi azas-azas umum pemerintahan yang baik agar tercipta kepuasan konsumen yang merupakan tolak ukur keberhasilan suatu pelayanan publik. Rumusan masalah
\end{abstract}


penelitian yaitu, bagaimanakah Azas-Azas Umum Pelayanan Publik Di Dinas Perindustrian dan Perdagangan Kabupaten Kerinci Tujuan penelitian yaitu, Untuk mengetahui Azas-Azas Umum Pelayanan Publik Di Dinas Perindustrian dan Perdagangan Kabupaten Kerinci. Penelitiaan ini menggunakan pendekatan kualitatif dimana data diperoleh melalui pedoman wawancara dilapangan kepada 7 orang informan yang mengacu kepada 6 indikator penelitian yaitu 1. Transparansi 2. Akuntabilitas 3. Kondisional 4. Partisipasi 5. Tidak Diskriminatif. 6. Keseimbangan Hak dan Kewajiban. Data yang diperoleh dilapangan dianalisis berdasarkan pengklasifikasian jawaban informan yang diuraikan dalam hasil dan pembahasan penelitian yang kemudian dilakukan interpretatif peneliti. Diketahui bahwa Azas-Azas Umum Pelayanan Publik Di Dinas Perindustrian dan Perdagangan Kabupaten Kerinci dari enam indikator penelitian lima indikator yang terlaksana dengan baik yaitu untuk indikator akuntabilitas, kondisional, partisipasi, tidak diskriminatif dan keseimbangan hak dan kewajiban sedangkan indikator transparansi belum terlaksana secara maksimal. Untuk itu penulis menyarankan agar Azas-Azas Umum Pelayanan Publik Di Dinas Perindustrian dan Perdagangan Kabupaten Kerinci dapat ditingkatkan agar dan lebih transparan dalam memberikan pelayanan kepada masyarakat.

\section{Kata Kunci : Azas-Azas Umum pelayanan Publik}

\section{PENDAHULUAN}

Salah satu peran utama pemerintah di masa sekarang ini adalah mampu memberikan solusi terhadap artikulasi dan merealisasikan kepentingan publik. Secara harafiah kepentingan publik berarti kepentingan umum, yang mencerminkan kepentingan organisasi atau kelompok yang ada dalam suatu masyarakat karena masyarakat selalu akan menuntut pelayanan yang berkualitas dan memuaskan.

Untuk mewujudkan pelayanan yang berkualitas dan memuaskan pemerintah harus menerapkan azas-azas umum pelayanan publik. Azas-azas umum pelayanan publik adalah hal-hal penting yang harus diperhatikan oleh pemerintah pada saat mendesain atau mengevaluasi tata cara dan tata aliran pelayanan pemerintahan. Asas-asas ini akan dapat memberikan pedoman tentang efektivitas, efisiensi dan akuntabilitas pelayanan. Pelayanan diartikan sebagai pemberian layanan (melayani) keperluan orang atau masyarakat yang mempunyai kepentingan pada organisasi itu sesuai dengan aturan pokok dan tata cara yang telah ditetapkan.

Setiap bentuk campur tangan pemerintah harus didasarkan pada peraturan perundang-undangan yang berlaku sebagai perwujudan dari asas legalitas, yang menjadi sendi utama negara hukum. Sejak dianutnya konsepsi welfare state, yang menempatkan pemerintah sebagai pihak yang bertanggung jawab terhadap kesejahteraan umum warga negara dan untuk mewujudkan kesejahteraan ini pemerintah diberi wewenang untuk campur tangan dalam segala lapangan kehidupan masyarakat, yang dalam campur tangan ini tidak saja berdasarkan pada 
peraturan perundang-undangan, tetapi dalam keadaan tertentu dapat bertindak tanpa bersandar pada peraturan perundang-undangan, tetapi berdasar pada inisiatif sendiri. Namun, disatu sisi keaktifan pemerintah dalam mengupayakan kesejahteraan umum haruslah senantiasa berdasarkan pada asas-asas umum pemerintahan yang baik. (Ridwan H.R. 2014:52)

Jimly dalam (Sadhu Bagas Suratno 2012:43) berpendapat bahwa dalam paham negara hukum segala tindakan pemerintahan harus didasarkan atas peraturan perundang-undangan yang sah dan tertulis. Peraturan perundangundangan tertulis tersebut harus ada dan berlaku lebih dulu atau mendahului tindakan atau perbuatan administrasi yang dilakukan. Dengan demikian, setiap perbuatan atau tindakan administrasi harus didasarkan atas aturan atau "rules and procedures $^{\text {ee }}$ (regels).

Fungsi asas-asas umum pelayanan publik dalam penyelenggaraan pemerintahan adalah sebagai pedoman atau penuntun bagi pemerintah atau pejabat administrasi negara dalam rangka pemerintahan yang baik. Dalam hubungan ini, Muin Fahmal ( 2012:54) mengemukakan bahwa asas umum pelayaan publik yang layak sesungguhnya adalah rambu-rambu bagi para penyelenggara negara dalam menjalankan tugasnya. Rambu-rambu tersebut diperlukan agar tindakan-tindakan tetap sesuai dengan tujuan hukum yang sesungguhnya.

Pelayanan publik mempunyai dasar-dasar tersendiri dalam menyelenggarakan pelayanan. Asas penyelenggaraan pelayanan publik adalah kepentingan umum, kepastian hukum, kesamaan hak, keseimbangan hak dan kewajiban keprofesionalan, partisipatif, persamaan perlakuan / tidak diskriminatif, keterbukaan, akuntabilitas, fasilitas dan perlakuan khusus bagi kelompok rentan, ketepatan waktu, kecepatan, kemudahan dan keterjangkauan.

Pelayanan publik diselenggarakan oleh aparatur pemerintahan di Dinas Perdagangan dan perindustrian dalam berbagai sektor pelayanan terutama dalam menyangkut hak-hak sipil dan kebutuhan dasar masyarakat. Sesuai dengan fungsi utama Dinas Perindustrian dan Perdagangan Kabupaten Kerinci adalah untuk mewujudkan sinergitas antara perencanaan, penganggaran, pelaksanaan dan pengawasan pembangunan masyarakat maka pemerintah perlu terus berupaya meningkatkan pelayanan yang berkualitas, transparan dan akuntabel.

Agar dapat memberikan pelayanan yang memuaskan bagi pengguna jasa, penyelenggaraan pelayanan harus memenuhi azas-azas umum pemerintahan yang baik agar tercipta kepuasan konsumen yang merupakan tolak ukur keberhasilan suatu pelayanan publik. Dimana pemerintah diberi kewajiban untuk mewujudkan bestuurszorg (kesejahteraan umum), yang untuk itu kepada pemerintah diberikan kewenangan untuk campur tangan (staats bemoienis) dalam segala lapangan kehidupan masyarakat. Artinya pemerintah dituntut untuk bertindak aktif ditengah dinamika kehidupan masyarakat khususnya masyarakat di Kabupaten Kerinci.

Setiap masyarakat tentunya sangat mengharapkan adanya azas-azas umum pelayanan publik dalam memberikan pelayanan kepada masyarakat khususnya pada Dinas Perindustrian dan Perdagangan Kabupaten Kerinci. Dimana dalam hal ini diindikasikan bahwa, azas-azas umum pelayanan publik belum terlaksana secara maksimal dalam memberikan pelayanan publik seperti : 
1. Masih rendahnya mutu pelayanan publik yang dilakukan oleh aparatur pemerintah Dinas Perindag Kabupaten kerinci.

2. Pelayanan publik yang diberikan belum dijalankan sesuai dengan azas-azas umum pelayanan publik seperti kurang ramah, kurang transparan dan kurang tanggung jawab dalam memeberikan pelayanan seperti ada berkas-berkas surat penting yang hilang dalam mengurusan.

3. Masih kurangnya keterbukaan dalam memberikan pelayanan publik.

Berdasarkan fenomena diatas maka penulis tertarik untuk melakukan penelitian dengan judul "Analisis Azas-azas Umum Pelayanan Publik di Dinas Perindustrian dan Perdagangan Kabupaten Kerinci”

Berdasarkan fenomena diatas maka penulis tertarik untuk melakukan penelitian dengan judul "Analisis Azas-azas Umum Pelayanan Publik di Dinas Perindustrian dan Perdagangan Kabupaten Kerinci”

Tujuan Penelitian

Untuk mengetahui analisis azas-azas umum pelayanan publik di Dinas Perindustrian dan Perdagangan Kabupaten Kerinci

\section{METODE PENELITIAN}

\section{Pendekatan Penelitian}

Dalam Penelitian ini penulis menggunakan pendekatan Kualitatif yaitu meneliti suatu objek penelitian dengan mengkaji secara keseluruhan dan mendalam bukan melihat hubungan dua variabel atau lebih. Dimana hasil penelitian akan diolah berdasarkan interpretatif peneliti dan diuraikan dalam bentuk deskriptif. Lexy J.Moleong (2009: 21)

\section{Informan Penelitian dan Teknik Penentuan Informan}

Informan penelitian adalah merupakan teknik pengambilan sampel untuk menentukan sampel yang akan digunakan dalam penelitian. Sugiono, (2007:91). Dalam penelitian kualitatif proses sampling yang terpenting adalah bagaimana menentukan informan kunci atau situasi sosial tertentu yang sarat informasi sesuai dengan fokus penelitian. Bugin, (2003:53). Pemilihan informan kunci diperolah secara purposive sampling yaitu sampel yang diambil secara sengaja dan informan biasa dilakukan dengan cara accidental sampling yaitu sampel yang ditemukan secara kebetulan di lokasi penelitian dan akan berhenti apabila jawaban dari informan sudah menemukan titik jenuh oleh peneliti yaitu pengawai di Dinas Perindustrian dan Perdagangan Kabupaten Kerinci.

\section{Data Yang Digunakan} adalah:

Untuk keperluan penelitian ini, adapun jenis data yang penulis gunakan

1. Data Primer, yaitu data yang diperoleh dari hasil penelitian langsung ke lapangan atau ke tempat penelitian melalui wawancara agar data yang didapatkan tepat dan benar di Kantor Dinas Perindustrian dan Perdagangan Kabupaten Kerinci. 
2. Data Sekunder, yaitu data yang diperoleh dari dokumen, arsip-arsip dan sumber lainnya yang berkaitan dengan penelitian ini, yang dapat menunjang penelitian dengan melihat relefansinya dengan permasalahan pelitian.

\section{Teknik Pengumpulan Data}

\section{Penelitian Perpustakaan (Library Research)}

Penelitian ini untuk mendapatkan data sekunder yaitu data yang diperoleh dilapangan melalui literatur-literatur ataupun referensi-referensi, untuk mencari landasan teori yang berhubungan dengan masalah yang dibahas, serta buku-buku yang menunjang proposal penelitian ini.

2. Penelitian Lapangan (Field Research)

Penelitian ini merupakan pengumpulan data yang dilakukan dengan cara turun langsung ke objek yang di teliti untuk mendapatkan data primer melalui :

1. Wawancara (interview)

Wawancara adalah teknik pengumpulan data yang melakukan percakapan antara dua orang atau lebih, yang pertanyaannya diajukan oleh peneliti kepada subjek atau sekelompok subjek penelitian untuk dijawab. Danim, (2002:130). Wawancara yang dilakukan adalah wawancara tidak tersrtuktur, adalah wawancara yang bebas dimana peneliti tidak menggunakan pedoman wawancara yang telah tersusun secara sistematis dan lengkap untuk pengumpulan datanya. Pedoman wawancara yang digunakan hanya berupa garis-garis besar permasalahan yang akan ditanyakan.Sugiyono, (2007:222).

2. Observasi (observation)

Observasi yang dilakukan yaitu dengan cara pengamatan tidak berperan serta, dimana pengamat hanya melakukan satu fungsi, yaitu mengadakan pengamatan lansung terhadap objek yang diteliti Lexy J. Meleong, (2009 :186). Sedangkan menurut Moh. Nazir. (2005:68), observasi yaitu cara pengumpulan data menggunakan mata tanpa ada pertolongan alat standar lain untuk keperluan tersebut.

\section{Unit Analisis}

Yang menjadi unit analisis dalam penelitian ini adalah azas-azas umum pemerintahan yang baik dalam pelayanan publik di kantor Dinas Perindustrian dan Perdagangan Kabupaten Kerinci.

\section{Interprestasi Data}

Interprestasi data mengacu pada tujuan penulisan ini yakni untuk mengatahui azas-azas umum pemerintahan yang baik dalam pelayanan publik di Dinas Perindustrian dan Perdagangan Kabupaten Kerinci. Peneliti menggunakan informan kunci dan biasa berdasarkan tingkat kejenuhan yang akan diperoleh dalam penelitian nantinya yang akan diwawancarai dengan menggunakan pedoman wawancara untuk memperoleh data dilapangan.

Interprestasi data yang digunakan dalam penelitian ini yaitu data yang diperoleh dilapangan dan diolah dengan menggunakan interpretatif peneliti untuk mengolah data mentah yang relevan yang diperoleh dilapangan kemudian hasil penelitian diuraikan dalam bentuk kalimat bukan angka-angka atau data statistik.

Menurut Miles dalam Emzir (2010 : 129) Analisa data ada tiga cara yaitu : 


\section{Reduksi data}

Reduksi data merupakan suatu bentuk analisis yang mempertajam, memilih ,memokuskan, membuang, dan menyusun data dalam suatu cara dimana kesimpulan akhir dapat diverifikasi. Data kualitatif dapat direduksi dan ditransformasikan dalam banyak cara yaitu melalui seleksi halus, melalui rangkuman atau parafrase.

2. Model data (data display)

Langkah kedua dari kegiatan analisis data merupakan model data. Model (display) dalam kehidupan sehari-hari berbeda-beda dari pengukuran bensin, surat kabar, sampai layar computer. Melihat sebuah tanyangan membantu kita memahami apa yang terjadi dan melakukan sesuatau-analisis lanjutan atau tindakan didasarkan pada pemahaman tersebut.

Bentuk yang paling sering dimodel data kualitatif selama ini adalah teks naratif. Manusia tidak terlalu kuat sebagai pemproses dari sejumlah besar informasi ; tendensi kognitif merupakan mereduksi inforrmasi yang komplek kedalam berbagai gestalt yang dipilih atau konfigurasi-konfigurasi yang mudah dipahami. Model tersebut mencangkup berbagai jenis matrik, grafik, jaringan kerja, dan bagan.

Merancang kolom dan baris dari suatu matrik untuk data kualitatif dan menentukan data yang mana, dalam bentuk yang mana, harus dimasukan kedalam sel yang mana merupakan aktivitas analisis.

3. Penarikan kesimpulan / Verifikasi

Langkah ketiga dari aktivitas analisis merupakan penarikan dan berifikasi kesimpulan. Kesimpulan akhir tergantung pada ukuran korpus dari catatan lapangan, penyimpangan, dan metode-metode perbaikan yang digunakan tuntutan dari penyandang dan tetapi kesimpulan bahkan ketika seorang menyatakan telah memproses secara induktif.

\section{Lokasi Penelitian}

Penelitian ini akan dilakukan di kantor Dinas Perindustrian dan Perdagangan Kabupaten Kerinci, dengan alasan berdasarkan pengamatan awal peneliti diindikasikan bahwa pelayanan publik belum terlaksana berdasarkan azasazas umum pemerintahan yang baik.

\section{HASIL DAN PEMBAHASAN}

Dalam penelitian ini pengambilan data dilakukan dilapangan dengan menggunakan pedoman wawancara dengan 7 orang informan di Dinas Perindustrian dan Perdagangan Kabupaten Kerinci dari tanggal 1 Juli sampai tanggal 16 Juli 2020 kemudian data diuraikan berdasarkan urutan indikator dari setiap informan, setelah itu dilakukan kesimpulan berdasarkan interpretatif dari peneliti pada setiap akhir indikator penelitian.

\section{Transparansi}

pegawai Dinas Perindustrian dan Perdagangan Kabupaten Kerinci belum melaksanakannya dengan baik dan maksimal, dimana hal ini sesuai dengan peraturan dan teori yaitu, transparansi publik merupakan merupakan baik dan 
buruk sikap atau tindakan dan perilaku manusia dalam berhubungan dengan sesamanya baik dalam masyarakat maupun organisasi publik atau bisnis dalam memberikan pelayanan publik, dimana pegawai sangat belum kooperatif dan tidak memberikan penjelasan yang baik dalam memberikan pelayanan kepada masyarakat dengan demikian sikap pegawai dalam memberikan pelayan kepada masyarakat kurang transparan apalagi berhadapan dengan masyarakat awam yang membutuhkan pelayanan yang sederhanan yang mudah dimengerti.karena tidak semua masyarakat yang membutuhkan pelayanan memiliki pengetahuan yang tinggi.

\begin{abstract}
Akuntabilitas
Akuntabilitas dalam azas-azas umum pelayanan publik di Dinas Perindustrian dan Perdagangan Kabupaten Kerinci telah melaksanakannya dengan baik sesuai dengan teori yaitu, sistem pelayanan publik yang akuntabel memiliki dua dimensi yaitu, bertanggungjawa terhadap pimpinan dan bertanggungjawab terhadap masyarakat sebagai menerima pelayanan. Dimana hubungan antar pegawai dengan masyarakat sangat baik hal ini dapat diketahui seperti setiap pegawai diwajibkan memiliki akuntabilitas pelayanan publik yang baik, sederhana dan tidak berbelit-belit dalam pengurusannya agar masyarakat dapat dengan mudah mengurus semua kepentingan mereka dan dapat dipertanggungjawabkan.
\end{abstract}

\title{
Kondisional
}

kondisional dalam azas-azas umum pelayanan publik di Dinas Perindustrian dan Perdagangan Kabupaten Kerinci telah melaksanakannya dengan baik sesuai dengan aturan dan perundang-undangan yang telah ditetapkan. Dan hal ini sejalan dengan teori yaitu, kondisi publik merupakan sarana merefleksikan nilai-nilai dan norma-norma yang ada di masyarakat dalam azasazas umum pelayanan publik agar tercipta kesesuaian pelayanan dengan nilai-nilai dan norma-norma yang di masyarakat dengan demikian akan berpengaruh terhadap terciptanya kondisional pelayanan publik yang baik dalam azas-azas umum pelayanan publik. Dimana dalam hal ini telah dilaksanakan sesuai dengan aturan yang telah ditetapkan dan pelaksanaannya tidak boleh menyimpang dan sudah adanya kontrol dari masyarakat agar terciptanya pelayanan publik yang sesuai dengan kondisi dan situasi yang ada dalam masyarakat.

\section{Partisipasi}

Partisipasi dalam azas-azas umum pelayanan publik di Dinas Perindustrian dan Perdagangan Kabupaten Kerinci telah melaksanakannya dengan baik sesuai dengan aturan dan perundang-undangan yang telah ditetapkan. Hal ini sejalan dengan teori dimana tingkat partisipasi, meliputi seluruh proses pelayanan publik, termasuk didalamnya adalah persyaratan, biaya dan waktu yang dibutuhkan, serta cara pelayanan. Azas-azas umum pelayanan sudah berusaha berpaartisipasi dalam menjelaskan kepada para pengguna mengenai persyaratan yang harus dipenuhi berserta alasan diperlukannya persyaratan itu dalam proses pelayanan.

\section{Tidak Diskriminatif}


tidak diskriminatif dalam azas-azas umum pelayanan publik di Dinas Perindustrian dan Perdagangan Kabupaten Kerinci telah melaksanakannya dengan baik sesuai dengan aturan dan perundang-undangan yang telah ditetapkan. Dimana azas-azas umum pelayanan publik sudah dilaksanaan sejalan dengan teori yaitu, tidak adanya unsur diskriminatif bagi siapapun yang ingin mendapatkan pelayanan, dan dapat dipahami oleh pengguna dan stakeholder yang lain. Maksud dipahami disini bukan hanya dalam arti literal semata tetapi juga makna dibalik semua prosedur dan peraturan itu. Penjelasan mengenai persyaratan, prosedur, biaya dan waktu yang diperlukan sebagaimana adanya merupakan hal yang paling penting bagi para pengguna dengan tidak diskriminatif yang ditetapkan oleh Dinas Perindustrian dan Perdagangan Kabupaten Kerinci.

\section{Keseimbangan Hak dan Kewajiban}

Dinas Perindustrian dan Perdagangan Kabupaten Kerinci telah melaksanakannya dengan baik sesuai dengan aturan kepada masyarakat yaitu, kemudahan untuk memperoleh informasi, mengenai berbagai aspek azas-azas umum pelayanan publik. Ada keseimbangan hak dan kewajiban antara pegawai yang memberikan pelayanan publik dengan masyarakat yang menerima pelayanan publik. Semakin mudah masyarakat memperoleh pelayanan maka masyarakat akan semakin merasakan bahwa hak-hak mereka dalam memperoleh pelayanan yang baik akan terpenuhi. Hal ingin berumpan balikkepada pegawai dengan mendapatkan respon yang baik dari masyarakat terhadap Dinas Perindustrian dan Perdagangan Kabupaten Kerinci.

\section{IV.SIMPULAN}

1. Transparansi pegawai Dinas Perindustrian dan Perdagangan Kabupaten Kerinci belum melaksanakannya dengan baik dan belum maksimal seperti pegawai masih kurang transparan dalam memberikan pelayanan dalam artian belum sepenuhnya memberikan penjelasan kepada masyarakat yang membutuhkan pelayanan dengan melemparkan tanggung jawab kepada pegawai lain untuk menjelaskan pertanyaan dari masyarakat yang membutuhkan penjelasan dalam pengurusan.

2. Akuntabilitas dalam azas-azas umum pelayanan publik di Dinas Perindustrian dan Perdagangan Kabupaten Kerinci telah melaksanakannya dengan baik sesuai kebutuhan masyarakat.

3. Kondisional dalam azas-azas umum pelayanan publik di Dinas Perindustrian dan Perdagangan Kabupaten Kerinci telah melaksanakannya dengan baik sesuai dengan aturan dan perundang-undangan yang telah ditetapkan.

4. Partisipasi dalam azas-azas umum pelayanan publik di Dinas Perindustrian dan Perdagangan Kabupaten Kerinci telah melaksanakannya dengan baik sesuai dengan aturan dan perundang-undangan yang telah ditetapkan.

5. Tidak diskriminatif dalam azas-azas umum pelayanan publik di Dinas Perindustrian dan Perdagangan Kabupaten Kerinci telah melaksanakannya dengan baik sesuai dengan aturan dan perundang-undangan yang telah ditetapkan. 
6. Keseimbangan hak dan kewajiban dalam azas-azas umum pelayanan publik di Dinas Perindustrian dan Perdagangan Kabupaten Kerinci telah melaksanakannya dengan baik sesuai dengan aturan kepada masyarakat.

\section{UCAPAN TERIMAKSIH}

Diucapkan terima kasih kepada semua pihak yang telah berkontribusi dalam penulisan jurnal ini, sehingga jurnal ini dapat diselesaikan dengan baik. Dan juga terima kasih kepada penglola jurnal Qawwam, sehingga bisa dipublikasan di OJS Qawwam.

\section{DAFTAR PUSTAKA}

Bugin, B 2003, Analisis Data Penelitian Kualitatif, Rajawali Pers : Jakarta. Danim, Sudarwan. 2002, Menjadi Peneliti Kualitatif, Pustaka Setia. Bandung Dyah Adrianti. 2016. Pendayagunaan Freies Ermessen Pejabat Pemerintahan Dalam Konsep Negara Kesejahteraan .Grafindo. Jakarta

Pebi Julianto. 2018. Pengaruh Pengetahuan dan Keterampilan Terhadap Prestasi Kerja Pegawai Pada Mtsn Model Sungai Penuh. E Jurnal Administrasi Nusantara. Sungai Penuh.

Hotma P. Sibuea. 2002. Azas Negara Hukum Peratauran Kebijkan Dan Azas-azas Umum Pemerintahan Yang Baik. Erlangga. Jakarta

Ismail Mohammad, 2011, Pelayanan Publik dalam era Desentralisasi.Jurnal.

Jazim Hamidi. 2009. Penerapan Azas-azas Umum Pemerintahan Yang Layak Di Lingkungan Peradilan Administrasi Indonesia. Citra Aditya Bakti. Bandung

Lexy J. Moleong. 2009. Metode Penelitian Kualitatif. Erlangga. Jakarta

Mahmudi. 2005. Asas-asas Pelayanan Publik, Pustaka Pelajar, Yogyakarta

Miles dan Emzir, 2010. Metodologi Penelitian Kualitatif Analisis Data, Jakarta: Rajawali Pers.

Pebi Julianto. 2018. Pengaruh Sistem Kearsipan Terhadap Efisiensi Kerja Pada koantor Camat Air Hangat Kabupaten Kerinci. E Jurnal Administrasi Nusantara. Sungai Penuh.

Muhamad Azhar. 2015. Relevansi Azas-azas Pemerintahan Yang Baik Dalam Sistem Penyelenggraan Administrasi Negara. Jakarta

Muhaimin. 2018. Penguatan Penyelenggaraan Pelayanan Publik Melalui Penyelesaian Sengketa Informasi Publik. Jurnal Ilmiah Hukum. Jakarta

Nurmandi Achmad, 2010, Manajemen Pelayanan Publik. Yogyakarta : PT.Sinergi Visi Utama.

Pebi Julianto. 2019. Pengaruh Disiplin Kerja Terhadap Prestasi Kerja Pegawai pada Puskesmas di kecamatan Depati VII Kabupaten Kerinci. E Jurnal Administrasi Nusantara. Sungai Penuh.

Philipus M. Hadjon. 2003. Pengantar Hukum Administrasi Indonesia.Gajahmada University Press. Yokyakarta

Ratminto. 2005. Manajemen Pelayanan Pengembangan Modal.Konseptual. Penerapan Citizen's Charter dan SPM. Yogyakarta : Pustaka Pelajar. 
Ridwan HR. 2014. Hukum Administrasi Negara. PT. Raja Grafindo Persada. Jakarta

Sadhu Bagas Suratno. 2012. Pembentukan Peraturan Kebijakan Berdasarkan Azas-azas Umum Pemerintahan Yang Baik. E jurnal Lentera Hukum. Jakarta

Pebi Julianto. 2014. Evaluasi Pelaksanaan Program Satu milyar Satu kecamatan (Samisake) di kecamatan Depati Tujuh Kabupaten Kerinci Provinsi jambi tahun 2014. OSF Preprints. Jakarta.

SF Marbun. 2001. Pembentukan, Pemberlakuan, dan Peranan Azas-azas Umum Pemerintahan yang Layak dalam Menjelmakan Pmerintahan yang Baik dan bersik di Indonesia. Bandung

Sinambela. 2011. Reformasi Pelayanan Publik. PT Bumi Aksara. Jakarta.

Sugiyono. 2007. Metodologi Penelitian. Jakarta : Penerbit Rineka

Pasal 53 UU No.5 tahun 1986 Tetang Azas-azas Umum Pemerintahan Yang Baik.

Undang-Undang No. 28 tahun 2011 Tentang Penyelenggaraan Negara

Undang-Undang No. 30 tahun 2014 Tentang Administrasi Pemerintahan

Peraturan Bupati Nomor 39 tahun 2019 Tentang susunan, fungsi dan tupoksi Dinas Perindustrian dan perdagangan Kabupaten Kerinci. 